\title{
Public Conversations Group as Resource Against LGBT Violence ${ }^{1}$
}

\author{
Laura Vilela e Souza ${ }^{2}$, Murilo dos Santos Moscheta ${ }^{3}$, Fabio Scorsolini-Comin ${ }^{2}$ \\ ${ }^{2}$ Universidade de São Paulo, Ribeirão Preto-SP, Brazil \\ ${ }^{3}$ Universidade Estadual de Maringá, Maringá-PR, Brazil
}

\begin{abstract}
The increase in violence against LGBT people (lesbian, gay, bisexual, transvestite, transgender and transgender) in Brazil encourages the adoption of preventive strategies, among them the Public Conversations Project (PCP), methodology for groups in conflicts. This study aimed to analyze the group process of the PCP, focusing on the effects of the structure of the conversation in the interactions undertaken. There were three meetings with a total of 13 participants involved in the issue of violence against LGBT people. The meetings were audio-taped, and the speeches analyzed according to social constructionism. The PCP has proved useful to think of a more human confrontation with the difference in favor of an ethical interest. It was possible to say that the creation of a different way of talking coincided with the emergence of new ways of acting. The effects of these meetings should be observed longitudinally, as well as trigger reflections for public policies of attention to LGBT.
\end{abstract}

Keywords: dialogue, violence, homophobia, groups, minority group

\section{Grupos de Conversações Públicas como Recurso contra a Violência à População LGBT}

\begin{abstract}
Resumo: O aumento da violência contra LGBTs (lésbicas, gays, bissexuais, travestis, transexuais e transgêneros) no Brasil incentiva a adoção de estratégias preventivas, entre elas o Projeto Conversações Públicas (PCP), metodologia para grupos em conflitos. Este estudo teve por objetivo analisar o processo grupal do PCP, com foco nos efeitos da estrutura da conversa nas interações empreendidas. Realizaram-se três encontros com o total de 13 participantes envolvidos com a temática da violência a LGBTs. Os encontros foram audiogravados e os discursos analisados segundo o construcionismo social. O PCP mostrou-se útil para se pensar um confronto mais humano com a diferença em prol de um interesse ético. Foi possível afirmar que a criação de um modo diferente de conversar coincidiu com a emergência de novas maneiras de agir. Os efeitos desses encontros devem ser acompanhados longitudinalmente, bem como disparar reflexões para políticas públicas de atenção a LGBTs.
\end{abstract}

Palavras-chave: diálogo, violência, homofobia, grupos, grupos minoritários

\section{Grupos de Conversaciones Públicas como Recurso contra la Violencia a la Población LGBT}

\begin{abstract}
Resumen: El aumento de la violencia contra LGBTs (lesbianas, gays, bisexuales, travestis, transexuales y transgéneros) en Brasil incentiva la adopción de estrategias preventivas, entre ellas el Proyecto Conversaciones Públicas (PCP), metodología para grupos en conflictos. Este estudio tuvo por objetivo analizar el proceso grupal del PCP, con foco en los efectos de la estructura de la conversación en las interacciones emprendidas. Se realizaron tres encuentros con el total de 13 participantes involucrados en la temática de la violencia contra LGBT. Los encuentros fueron grabados en audio y los discursos analizados según el construccionismo social. El PCP se mostró útil para pensar una confrontación más humana con la diferencia a favor de un interés ético. Es posible afirmar que la creación de un modo diferente de conversación coincidió con la emergencia de nuevas maneras de actuar. Los efectos de estos encuentros deben ser acompañados adelante, así como disparar reflexiones para políticas públicas de atención a LGBT.
\end{abstract}

Palabras clave: diálogo, violencia, homofobia, grupos, grupos minoritarios

\footnotetext{
${ }^{1}$ Support: This study was developed with the financial support of the Fundação de Amparo à Pesquisa do Estado de Minas Gerais FAPEMIG (Process APQ-02062-12)

Correspondence address: Laura Vilela e Souza. Universidade de São Paulo. Faculdade de Filosofia, Ciências e Letras de Ribeirão Preto. Rodovia dos Bandeirantes 3900, Ribeirão Preto-SP, Brazil. CEP 14.040-901. E-mail: laura@ffclrp.usp.br
}

In Brazil, there are still no consistent and fully shared statistics on violence against the LGBT population (lesbian, gay, bisexual, transvestite, transsexual and transgender), partly because of the recent lack of protocol for inserting sexuality issues into police reports and even of a social and cultural process that recognizes such crimes as related 
to the gender (Fernandes, 2013; Ramos \& Carrara, 2006; Silva, 2007) which hinders the promotion of policies and strategies aimed at the protection of these people, as well as of punishment of the authors of the most diverse forms of violence (Carrara, 2012; Efrem Filho, 2016; Perucchi, Brandão, \& Vieira, 2014). In a recent survey carried out by the Gay Group of Bahia (GGB) (2017) from secondary sources, such as information on groups and acquaintances of the victims, every 25 hours an LGBT person died of violence in Brazil in 2016. In 2016 a record was registered, with 343 deaths. In 2017, until September 20, there were 277 homicides of LGBTs. In terms of vulnerability, transvestites and transsexuals are the population that suffers the most violence. According to Transgender Europe (TGEU), Brazil is the country that kills most transvestites and transsexuals in the world, with 295 cases of murders between October 2015 and September 30, 2016 (LaGata, Balzer, \& Berredo, 2016).

To these data are added few advances in public policies (Mello, Avelar, \& Maroja, 2012), as pointed out in the report, which does not allow us to foresee a less violent scenario in the future (GGB, 2017). As pointed out by Fernandes (2013), recovering several GGB surveys since the 1980s, high rates of lethal violence against LGBT people reveal different social hierarchies marked by class and gender, victimizing, for the most part, poor transvestites or homosexuals, involved in prostitution and residents of peripheries. Several social movements and their militants have pointed out the need to establish public security policies for the LGBT population, given the proliferation of discourses that spread an idea of intolerance to sexual diversity, manifested in the discourse of representatives of various institutions such as churches, political parties and communication media (Mello, Avelar, $\&$ Brito, 2014).

Such positions are at the basis of the explanations offered about the behaviors of intolerance that culminate in violence, that is, the inability to sustain difference and, more than that, to dialogue with it in its interface with education (Vianna, 2015). These aspects are relevant when we consider LGBT issues, which triggers the need to develop social technologies that can combat precisely this scenario of intolerance and prejudice that is often expressed in acts of violence, often fatal (Efrem Filho, 2016; Perucchi et al., 2014).

Based on this social justification and the absence of public policies aimed at the protection of these social minorities in the Brazilian context, the Public Conversations Project (PCP) was implemented in the country with a view to discussing violence against the LGBT population, among other topics of interest and promoters of social conflicts, with experiences carried out in cities in the states of São Paulo, Minas Gerais and Paraná (Apóstolo, Moscheta, \& Souza, 2017; Moscheta, Souza, Casarini, \& Scorsolini-Comin, 2016; Souza \& Moscheta, 2016).

The scientific literature presents some proposals of groups with participants in conflicts, especially in the international scenario (Dessel \& Rogge, 2008, Forester, 2012, Wayne, 2008). However, the PCP seeks a distinct direction, which is the non-production of discourses of agreement, but of acceptance of the other and of mutual understanding. The PCP has as one of its objectives the promotion of common understandings, although the participants continue to support their initial positions on a certain theme. It is intended, therefore, to promote listening, greater tolerance and even the possibility of coordinating joint actions and not convincing the other to the possible change of position. It is hoped that the participants can open themselves to listening to the other, also experiencing this place, so that transformations can occur in the way these people see each other, understand each other and live together (Herzig, 2011).

This conversation methodology was created by a North-American institution of family therapy and dialogue facilitation originally called the Public Conversations Project, now renamed Essential Partners, located in Cambridge, Massachusetts. It provides a structure of conversation based on previous agreements with its participants on respect and mutual listening, in a notion of dialogue that does not seek consensuses and agreements, but the support of various moralities in the conversation, in overcoming a rhetoric of convincing and persuasion, replacing it with questions of curiosity about the way of thinking of others and the notion of language as constructor of realities, understanding that the way to prepare people for the conversation, the agreements of trust, the choice of questions to be asked for the people during the meeting are the driving elements of the change that is intended for the conversation (Chasin et al., 1996).

At PCP, the purpose of the meeting is a space in which people can experience new ways of interacting with people who are usually distant from each other or in direct or indirect conflict. The isolation of groups that think differently contributes to the creation of stereotypes. Therefore, some questions are asked as a way of promoting this novelty (Herzig $\&$ Chasin, 2006). The first question seeks to understand how, from each person's life experiences, each participant came to think of the way he or she currently thinks about the topic. The effect of this question on the group is usually that of people becoming empathetic to those who think differently, even though they continue to disagree with that thought. The second question is about at what times it is difficult for the participant to sustain their opinion on the subject. The idea is not to weaken positions, but to explore that any opinion about the world opens some possibilities for action, but limits others, and that the risk of absolute certainties may be the intolerance, inflexibility and impossibility of joint action for common good. Finally, there is room for participants to ask questions of legitimate curiosity.

In previous studies, we have followed the structure of the PCP presented here to address issues related to LGBT rights (Apóstolo et al., 2017; Moscheta et al., 2016; Souza \& Moscheta, 2016). In these groups, the purpose of the conversation was that people with polarized views on issues such as same-sex marriage or the law that criminalized homophobia could explore their differences in a space of dialogue rather than debate / conflict. We believe that the dialogue structure of the PCP allowed the equalization of the most diverse worldviews of the people, offering the same 
space of listening and respect to any opinion that could appear in the group. However, what could at first be coherent, based on the epistemological relativism that supports this proposal, came to be problematized when we questioned the ethical purposes of such practice.

We understand that the ethical parameter to evaluate a good dialogue is not only the possibility of the multiplicity of meanings in the conversation, but the analysis of the purpose of the exploration of this multiplicity. In the case of LGBT violence, it is important that people who are radically different in their opinions are in conversation, since all of them may be involved in the construction of violent or preventive actions; however, the "why" of the conversation must respond to the common and ethical purpose of ending this violence. Based on this and as part of our research on the applications of the PCP in Brazil, we promoted a group with three meetings in which we introduced some changes in the original PCP structure that sought to respond to these reflections.

The changes were in terms of number of meetings (more than a meeting with the same participants), group composition (more participants and people clearly recognized as social leaders) and organization and sequence of questions asked (inclusion of propositional questions, aiming possible joint actions). From this perspective, the objective of the present study is to analyze the group process of these PCP meetings focusing on the effects of the conversation structure (and the adaptations we make) on the interactions undertaken. The analysis of a methodology that has been used successfully in several countries can be a useful tool in the work on public policies of attention to LGBT people, sensitive to the scenario of violence against this population in Brazil.

\section{Method}

\section{Participants}

The groups were carried out in a city in the interior of the State of Minas Gerais, Brazil. A large part of their citizens stood out at the time of the meetings for the social importance given to the rich families of the city and many people denounced situations of racism, gender and sexual prejudice, and conservatism in custom. The participants of the groups studied here reported the difficulty of assuming their sexual orientation to the family and at work, the non-acceptance of gay couples in condominiums of "families of good," verbal and physical violence against transvestites who prostitute themselves in the main avenues of city, the difficulty of their lives, the lack of support from the local press to help social movements and militants, and the abuse of political power in some situations. The 13 participants are presented here from the way they positioned themselves in the group. Some mentioned the reasons for having accepted to participate in the PCP, which allows us to understand how they have taken part in group meetings. Not all participants were present at all sessions. Table 1 summarizes this information.

Table 1

Presentation of Participants in Terms of Characteristics and Motivations for Participation in Meetings $(N=13)$

\begin{tabular}{|c|c|c|c|}
\hline Name & $\begin{array}{l}\text { How he or she presented himself or herself in } \\
\text { the group }\end{array}$ & Reasons to join the PCP & $\begin{array}{l}\text { Meetings in } \\
\text { which the } \\
\text { participant was }\end{array}$ \\
\hline Osmar & $\begin{array}{l}\text { Stylist and organizer of the LGBT week and } \\
\text { Parade. }\end{array}$ & $\begin{array}{l}\text { Highlights lack of police support regarding Gay } \\
\text { Parade and violence against transvestites. }\end{array}$ & 1 \\
\hline Jonas & $\begin{array}{l}\text { Gay militant, researcher of gender and } \\
\text { sexuality. }\end{array}$ & Situations of discrimination in the University. & 1 \\
\hline Paulo & 27 years old, councilor, lawyer & Opportunity to strengthen and fight against violence. & 1 \\
\hline Tereza & Educational technique & $\begin{array}{l}\text { Be sensitive to issues such as exclusion and prejudice. } \\
\text { Wants to collaborate. }\end{array}$ & 1 and 2 \\
\hline Lucia & Gay Pride Parade Organizer & Concern about episodes of lethal violence in the city. & 1 \\
\hline Juliana & $\begin{array}{l}24 \text { years old, lesbian, feminist, militant; does } \\
\text { not identify herself as a lesbian at work because } \\
\text { she fears prejudice. }\end{array}$ & $\begin{array}{l}\text { Perception of increasing hate speech in the media and } \\
\text { politics. }\end{array}$ & 1,2 and 3 \\
\hline Celso & $\begin{array}{l}\text { Deputy, a human rights activist, a militant in } \\
\text { the dictatorship. }\end{array}$ & $\begin{array}{l}\text { He highlights his history of defending human rights } \\
\text { and respect for sexual diversity and other differences. }\end{array}$ & 1 \\
\hline Henrique & 33 years old, priest. & $\begin{array}{l}\text { He is a teacher and has met homosexuals in situations } \\
\text { of suffering. }\end{array}$ & 1 and 2 \\
\hline Cristina & $\begin{array}{l}33 \text { years old, a militant in social movements, a } \\
\text { social worker, in a homo-affective relationship } \\
\text { of nine years. Teacher. }\end{array}$ & $\begin{array}{l}\text { The sister lived domestic violence for many years. } \\
\text { She was beaten by her mother and had contact with } \\
\text { episodes of violence suffered by LGBT students. }\end{array}$ & 1,2 and 3 \\
\hline Carlos & Gay, actor, theater director. & $\begin{array}{l}\text { Interest in the debate and build together, be part of this } \\
\text { conversation. }\end{array}$ & 1,2 and 3 \\
\hline
\end{tabular}


...Continuation

\begin{tabular}{lll}
\hline Name & $\begin{array}{l}\text { How he or she presented himself or herself in } \\
\text { the group }\end{array}$ & Reasons to join the PCP \\
\hline Daniela & $\begin{array}{l}\text { Graduated in social sciences, interested in the } \\
\text { feminist movement. }\end{array}$ & $\begin{array}{l}\text { Meetings in } \\
\text { which the } \\
\text { participant was } \\
\text { against transvestites. }\end{array}$ \\
Lauro & $\begin{array}{l}\text { Pastor, married, heterosexual, } 33 \text { years old, } \\
\text { works with logistics. }\end{array}$ & $\begin{array}{l}\text { Because he is a presbyter in the Assembly of God } \\
\text { Church and he stands for respect and love. }\end{array}$ \\
Larissa & $\begin{array}{l}\text { Graduated in social sciences, heterosexual, } \\
\text { militant feminist. }\end{array}$ & Victim of violence by an intimate partner. \\
\hline
\end{tabular}

\section{Instrument}

As this is an exploratory, descriptive, cross-sectional, qualitative study based on the theoretical-methodological framework of social constructionism and on the methodology of the PCP (Public Conversations Project) (Herzig, 2011), it is not expected to apply instruments of evaluation, but precisely the composition of the analytical corpus from the occurrence of the groups, represented in the meeting sessions, transcribed in full and literally, as described in the item Procedure.

\section{Procedure}

Data collection. All the people invited to participate in the groups were contacted because they were social leaders in different segments and because they had the potential to influence opinion and build actions to reduce LGBT violence in the city. Participants were recruited through various media, such as e-mail, social networks and telephone contacts. Before the groups were held, the volunteers were interviewed by the team of researchers (so-called "premeeting conversation"), to resolve possible doubts and clarify the meetings, topics to be addressed, their objectives and methodology. It was a time of greater alignment with the project proposal in which the volunteers were able to regain personal interest and engagement in the study. In these conversations were also presented and signed the Terms of Free and Informed Consent.

The groups were held in 2014 on consecutive days: 1st meeting: Reception of the participants, presentation of the team (facilitators, observers and support staff). At the beginning of the first meeting, agreements were made for the conversation (do not interrupt the speech of others, respect the speaking time stipulated by the facilitators, do not speak as a representative of any group or institution, listen to the other with curiosity, avoid abstract speeches about the theme). The triggering question for the group was: "Who are you and what story could you share with this group that would help us understand why violence against the LGBT population has worried you'. This question is inspired by the first question proposed by the PCP. The participants presented themselves and brought the motivations to participate in the group; 2nd meeting: The facilitators resumed some points of the organization of the conversation of the previous day, and opened space for questions of curiosity. They then explored with each participant what they would like to continue to do about reducing violence against LGBT people (valuing resources that already existed), which they should stop doing (focus of the conversation inspired by the purpose of the second question of the PCP structure ) and what they could begin to do from this conversation (the possibility of the conversation generating concrete actions, an adaptation to the structure of the $\mathrm{PCP}$ ); 3rd meeting: Resumption of agreements, exploitation of the elements necessary to undertake actions to deal with violence against LGBT people in the city, listed in the previous meeting and finalization of the group.

Data analysis. All encounters were audio recorded and transcribed in full and literally, composing the analytical corpus. The strategies of analysis of meanings produced were based on the following steps described by Rasera and Japur (2001): (1) Transcript readings; (2) Sequential analysis of the corpus, summarizing each group and identifying the speeches of each participant; (3) Construction of procedural and thematic axes, identifying topics discussed and interactions in the group; (4) Selection of cuttings of interactive moments indicative of specific meaning construction. The theoretical-methodological framework on which the analysis was based was the social constructionism (Gergen, 1999; McNamee, 2008), emphasizing the microssocial processes and the dialogic and polysemic nature of language (Rasera \& Japur, 2001), in line with the assumptions of the PCP (Herzig, 2011; Herzig $\&$ Chasin, 2006) adapted to the Brazilian context (Moscheta et al., 2016). The project that originated this study was approved by the Research Ethics Committee of the State University of Maringá (Protocol n ${ }^{\circ}$ 01647512.5.0000.0104) and the Federal University of the Triângulo Mineiro (Process No. 2238). 


\section{Results and discussion}

From the purpose of analysis of the effects of the conversation structure on the interactions undertaken, the construction of the procedural and thematic axes allowed the delimitation of the following axes of analysis: 1) The problematization of the participants' absences; 2) The participants' reflection on the way they talk about the topic; 3) Inspirations for future actions. Each axis is discussed from the highlights of the interactive moments (in the three group sessions) related to them.

\section{Axis 1: Who are the People Who Decide to Continue the Conversation}

One effect of more than one PCP meeting was the absence of participants at the second and third meeting. Only seven of the 13 participants returned, which made participants comment on this absence. For example, early in the second group, Larissa said she would like to have talked to Lucia about her use of the Gay Parade to make propaganda for city politicians. Larissa also wished she had talked to councilor Paul to question whether what he had understood as abuse of transvestites from being naked at the parade and embracing heterosexual men could be re-signified as an act of resistance from them by using their bodies as a protest. Larissa also said she wished she had the opportunity to talk with Pastor Lauro to ask if his statement that he respected and loved LGBT people was about a way to love, but at the same time, he wanted the other to change his or her sexual orientation.

It was important in this first meeting to talk about why Larissa and others wanted those who did not come back to be present. Daniela states:

Daniela: I understand all the afflictions of Larissa because we come from a militancy, it is difficult for us to arrive at the methodology that we must listen to the other and ... It's an interesting work, right? For those who are not used to things like that, because we think, just like when I was invited at the beginning, I thought we were going to come to a debate, right?

The frustration of the absence of these people in the group was re-signified, by the facilitator, as a possibility to be in conversation with those who want to think together:

Facilitator: But since we cannot talk about Lucia, I wanted to hear what Larissa's worries are, because she talks like that, Lucia cannot see how I can see, but Larissa can see, so I wanted to . . . I wanted to ask Larissa which scenario is the one she sees, so we can think along with who is here.

For Daniela the experience of debate in the militancy would mark the frustration with the absence of the people and the possibility of a conversation marked by the discordance and argumentation. So would it be useful to talk to someone who thinks similar about the subject?
The PCP proposes group composition not from the possibility of confrontation with those who think differently, but from the potential of the encounter between key people who can collaborate with each other in actions related to the theme. Therefore, from this purpose, and in line with the constructionist proposal, it does not interest the radicality of opinions in the group if they do not serve to exploit difference that seeks "bridges between immeasurable morals," as McNamee (2008) states. According to this author, when someone feels heard, he or she has a greater openness to listening and can start questioning his or her own certainties from a climate of mutual respect.

The mode of conversation in the PCP starts from a notion of dialogue that shares with the social constructionist perspective the understanding that there is no direct relation between knowledge and the perception of "reality", being possible different versions of reality from social practices, cultural and historical responsible for its construction. Thus, it is not possible to make an assessment of people's opinions in terms of being "more or less true" or reliable "to" reality (as in the case of the evaluation of Larissa's opinions compared with those of Lauro, Lucia and Paulo), but there is a possibility that these opinions can be questioned in terms of their pragmatic effects, in the case of the effects of producing or not of violence against LGBT people. This is what Ibáñez (2001) will consider as a position of a relativistic relativism, as opposed to absolutist relativism that is not able to put its own relativization movement into analysis. What becomes the subject of problematization here is pragmatic of language.

Thus, in the PCP, from a constructionist reading, the challenge is precisely to open space for this diversity of rationalities when the effects produced are in favor of the ethical parameters involved in the conversation. That is, the exploitation of difference in the group only makes sense if it is in favor of non-violent and prejudiced actions. A clear ethical positioning guides the possibility of dialogue not to fall into a relativism in which any content of the conversation is possible by the simple appreciation of difference.

\section{Axis 2: Beware with the Way of Talk}

Another effect of the conversation structure on group interaction was the way in which the participants were transforming their way of talking between them, taking care to comply with the dialogue agreements. At first, the way the facilitators talked, based on the guidelines of the PCP and the notion of facilitating dialogue in the social constructionist perspective, caused strangeness. Carlos, in the second meeting, asked why the facilitators were talking to each other, questioning the group's conduct with each other, in front of the participants (a posture of transparency and co-responsibility), which to him seemed like a "theater". But most of the participants evaluated this form of conversation as positive, understanding it as liberating, generating trust, allowing the other to hear, even though it also provoked anxiety at some moments, concerns and left the doubt of what concrete actions of change it could generate. In the third meeting the feedback offered was: 
Juliana: . . I I sometimes felt very comfortable, at other times a little dashing, but that is my way, the fear, you know? ...

Carlos: ... It was good, right, that opportunity of the person to entrust to you something of his or her life, that's priceless . . . without policing, let the thing roll, flow...

Daniela: Oh! I think I'm leaving very restless, this format is very different, we do not know what's going to come from there, we get very curious, I at least got very curious. I think it's good and sometimes I think it's bad, because sometimes I think I could promote the debate more, I do not know if we come from other experiences ... I think that... maybe this immediacy is even bad, but we really want that an effect should come quickly.

Larissa: I'm very happy, I never thought I would participate in such an experience ... Funny that at no time did I feel inhibited or embarrassed to speak, on the contrary, it seems that it gave me more courage.

Not just for the conversation itself, but the conversation mode was considered useful, to evaluate the way they were talking to people in their daily lives.

Tereza: I want to stop responding sharply to people who express prejudice in their speeches and attitudes, I do not have the slightest tolerance. So when someone is ... or even show some prejudice, I cannot have that dialogue, that loving way (refers to the way of conversation in the group), I go into the situation, I tell him or her to thread the prejudice in certain holes, I sometimes low the level even... So ... which is something that will not contribute to anything, so I must take a deep breath and either not respond or respond in a way that I can get that person to dilute, right?

Larissa: I always come into conflict with some people, I do not have much ... patience, just as Tereza said, to overcome certain points of view, we still have to work on it; yesterday, for example, I laughed yesterday, when some people were talking I looked and laughed I should not have had that attitude.

Daniela: Sometimes I'm a little incisive in the way I talk . . . It seems that I have all the weapons to empower the other, and I do not think that's cool, when in fact I do not know if that's the way.
The possibility of the form of dialogical conversation is thought of in the PCP proposal as an alternative to avoid the effects of offense, distance, conflict, debauch and imposition on the other. In the social constructionist perspective, the group structure is thought in terms of its effects on the positioning games between people (Rasera \& Japur, 2001). In the case of the meetings analyzed here, the search for the facilitators was in the sense that these positions put people with opposing opinions in the direction of common good. Or, as the facilitator said at the second meeting:

Facilitator: Our invitation to you today is to make the exercise of putting aside the will to be right and focus on the possibility of building alliances. So the question is: What would it be like to have a conversation where being right was less important than being with the other?

This invitation should be understood in accordance with its framework within the process of this group. This 'other' is already defined as someone who is interested in producing actions to reduce violence against LGBT people by the very framework that the invitation to participation in that group produces. The other is not 'any other', but someone with similar interests and with whom it would be possible to establish promising partnerships. Hence the pragmatic justification, which is echoed in the theories of conflict mediation and facilitation of social constructionist dialogues (McNamee, 2008), the invitation of the facilitators that calls the participants to move from the defense of their opinions to the defense of their interests. Focusing on interest allows participants to exercise cautious movements in the way they speak in the group. An example can be highlighted when Daniela, before asking a question for Larissa, was in doubt whether it would be a clarification question or if she was judging the opinion of other and decided to ask the facilitator if it was a useful question or not: "Daniela: I wanted to know if I could ask a question about her speech? To try to understand this...". Facilitator 2: Do you want to ask the question? Do it for me, we'll see.". Daniela: "If she does not think it is important who is leading the movements to be someone who suffers from prejudice, who has to start from them, or if she thinks anyone can do it.". Facilitator 1: "I think it is important to try to refine this question.". Facilitator 1: "Do you want to ask her who she thinks should lead LGBT rights movements?". Facilitator 2: "But you're already stating this for her?" Facilitator 1: "No, she's in doubt, I think she's in doubt.". In this passage, Daniela and the facilitators talk in Larissa's presence about how Daniela could ask her question. The effect of this type of intervention is to create a gap between the question and the response to produce a reflection about 'how to speak'. Larissa, seeing this conversation, can understand not only what Daniela wants to know, but also, and especially her care in talking to Larissa. This influences the whole group's conversation mode, as we can see moments later, when Cristina made a similar request to the facilitator: "Can 
I ask a question for you and do you also evaluate?" The caution here was that questions were not asked in the group that would become refutations of what the other spoke, as advocated by the PCP. It was one thing for Daniela to be interested in knowing what Larissa's opinion about who should lead social movements in the face of different ways of thinking about this issue, another thing was a question that already pointed out that the right way to think, a way in which only people who suffer prejudice can be in front of these initiatives.

Faced with the controversy that this theme raised in the conversation, the facilitators suggested rephrasing the question to everyone present and using the clock feature to set a maximum speaking time for each one. The reformulated question was: "With regard to the question of the leadership of social movements, what is my current way of looking at this, what doubts do I have and what are successful experiences on this issue?" The purpose here was to explore the multiplicity of ways of answering this question.

If from a constructional social understanding of language, we take the statements in the group as actions - language in its performative character (McNamee, 2008) - we understand that the coordinators' stance to help participants select questions from their effects proposes a new way of producing meanings in the group. The game of 'ask to unmask the fault in the other's argument' is replaced by the game 'ask to know the difference'. This displacement is possible to the extent that during the conversation the participants pass, through the interventions of the coordinators, to perceive what their speeches do in the group. In terms of communication models, we can identify the transition from a model of transmission of message to a constructionist model of joint production of meanings (Serra, 2007).

Nevertheless, dialogue is not defended as the best or only possible way of dealing with violence against LGBT population, because different social spaces call for specific interactions, and the rhetoric of argumentation is recognized by the militants as a privileged way of defending LGBT rights. To think about the effects of each of these forms of conversation in the field of LGBT militancy is the invitation that this study proposes. The PCP can be a strategy precisely to think about how it is possible to remain with the other for an ethical interest and focus not on certainties, but "under what conditions they can generate more human forms of confrontation with difference" (McNamee, 2008, p. 6).

Gergen (1999) argues that one of the great social constructionist contributions to militant movements was to collaborate with a critical discourse on essentialist and pathological theories about the human being and question the privilege of modern science in describing the world. This collaboration was later questioned insofar as the social constructionist perspective was denounced by these same militants as being in a position of non-action, of an empty critique of political positioning and defense. The author's response to these questions presents his defense of social constructionism as a politically implied discourse, since we will always be acting in the world, with PCP being one of these possible actions. However, he understands that it is not coherent to charge from social constructionism a position of defending an ethics fundamentally superior to others, even if this ethic is in defense of a marginalized group. Authors who dialogue with the social constructionist perspective defend a relational ethic in which any positioning is sustained not in a privileged vision of right and wrong, but in the relational course of each group and community, recognizing its historically constructed character and avoiding to fall into the same error that modern science fell, which was to understand itself as the source of absolute truths. The need for ethical and political positioning in professional practice should not be synonymous with the defense of transcendental ethics, but the constant questioning of the effects of moment-to-moment conversation (Trindade \& Rasera, 2013).

This relational ethics supports the practice of the PCP and it is from this that it is possible to evaluate when the conversation is offering space for the hearing of difference to happen or when it is repeating interactive patterns that alienate people and, in our opinion, collaborate for the maintenance of the violence that one wants to avoid and the crystallization of discourses and positions. It is a tenuous limit that requires constant reflexivity of the facilitators in proposing conversations like those of the PCP with groups that defend rights that they also defend.

In a study of the PCP approaches to social constructionist discourse, Rasera (2017) argues that the PCP with activists can be an "alternative to the relations of distrust and victimization between groups" (page 422), and space for exploration of "inadequacies in language and concepts used in public debates" (p. 422). This author affirms that the PCP can contribute to social change from "revitalizing the process of public discussion" and "combating demonization in the political struggle" (page 422), being "a relational proposal for collective challenges" (p. 428). Nevertheless, the author points out that structures of conversation such as the PCP should not end up leading to the "appeasement" of the claims of those who are discontented, preventing relevant social changes from occurring or a "cultural domination" (page 427). To avoid these dangers, the author suggests that the facilitators' commitments are not only with the process of dialogue, but also with their effects, a point also defended by Souza and Moscheta (2016).

\section{Axis 3: Inspirations for Future Actions}

In this axis of analysis, we highlight the effects of the group in building possibilities for future actions led by the participants to reduce violence against LGBT people. At the third meeting of the group, participants spoke in response to a question about what they would like to start doing about violence against LGBT people: the importance of being spontaneous and provocative in social environments, of organizing spaces for the participation of LGBT people in collectives of gender, to take care of the political co-optation of social movements, to help transvestites to create their own associations, to produce anti-homophobia materials in the city's media, among other actions. 
Considerations about what might be an action produced by the PCP meetings were present in the group when Juliana, at the beginning of the second meeting, pondered what she experienced in the first meeting. She reported her discomfort at being in a conversation that, for her, would not reach the proposed goal:

Juliana: Yesterday in the speech of everyone I could not see how we will get to an $\mathrm{X}$ point to try to head what we can do to lessen this violence, do you understand? I could not see this in anyone's speech, not in my speech, understand? . . . So, I could not see, for example, in Henrique's speech, the fact that he is a priest, what his parish provides for these eventual episodes ..."

For Juliana, the group's objective was to organize concrete actions regarding the reduction of violence against LGBT people. Being part of a militancy collective and having organized protest events in the city, she seemed to seek a conversation about what and how to do. Her strangeness derives from her impossibility to understand, at that group moment, the dialogical exercise itself as an action. It is important to note how it changes throughout the group process. At the end of the second meeting, when she answered the question of what she would like to continue to do, Juliana stated that she wished to continue participating in conversations like these, indicating that her discomfort was also accompanied by a positive appreciation of the conversation. Later, Juliana identified a possibility of cooperation with Henrique and invited him to participate in a meeting in the collective in which she participated: "Juliana: I would find it very interesting to hear you, you know? Regardless of the posture, what you're going to say, I think it's very important to listen to people and I wanted to hear you.".

As in the course of Juliana in the group, Henrique was also able to take advantage of the meetings to build possibilities of actions. In the second meeting, in reporting what he wanted to continue to do, he replied that he identified a lack of strategic vision of the LGBT movement in the city when they organized events and did not call some people. He described how he was engaging to promote discussions on gender and sexuality in his activities as priest and teacher, and how much such discussions allowed more conservative religious people to open for the conversation. Daniela replied that it was necessary to think about the strategy to be used and reported a situation in which a gender researcher gave a lecture to a very small public despite the good publicity. Henrique did not feel understood. He was talking about himself as someone who has occupied a prominent place and influence in the gender discussions promoted by the Catholic Church and could help the LGBT movement. Then, he asked to reformulate his speech in a request: "My request is to turn my concern into a request, I, Henrique. I would very much like to be invited to more initiatives; to use a little who I am, what I do and what I think.".
In remaking his speech, Henrique emphasized not only what he wanted to ask the group (to be more invited) but also what he offered to the group ("use a little who I am"). The possibility of Henrique to restate his speech in a request to the group seemed to be a consequence of the way the facilitators intervened throughout the group process in attempting to institute a new way of talking, as discussed in Axis Two. What emerged at this moment of the group was the construction of a possibility of unprecedented partnership, directly related to a way of talking also unprecedent. At the end of the third meeting, when Juliana answered a question about what she could begin to do about reducing violence against LGBT people, she emphasized the importance of knowing the active movements in the city and building partnerships. She resumed the experience of the second meeting and her conversation with Henrique and affirmed the importance of what she called "dialogism" in the construction of partnerships:

Juliana: This issue of creating more partnerships is very important to the issue of dialogism, you know? Let's search, just like the priest . . . Henrique said, right? There is this ... would you imagine that he and a secretary of state? And a super-open person, right? I was so surprised, because I found it super funny, because I had gone to a mass of him.

At the end of the third meeting, Cristina reported how she felt after participating in the group. She helps to understand that the risk of exposing oneself to the group, for example being at the same time as a different and an interested one, is also the possibility of being accompanied:

Cristina: I leave here re-thinking myself, because I thought a lot since the first day I came here, in everything I said; I thought if I exposed myself . . . but I felt very at ease, I spoke of my life in a clear and spontaneous way. I leave satisfied not to see myself alone as a category, as a social and political subject, and therefore I feel contemplated in the sense that I spoke, and I heard.

The actions listed by the participants to deal with the context of violence against LGBT people were related to what each one thought of as possibilities from their life contexts and did not necessarily include the collaboration of others in the group. It is therefore necessary to consider that the effects of the group on the possibilities of actions must be taken in at least three dimensions. In its first dimension, the group fosters an exchange that inspires its participants to act in their contexts. In its second dimension, the group creates possibilities of schedules among the participants that invite the construction of partnerships outside the group. And in its third dimension, the group does something with the participants and in this sense is an action that takes place in the present time of the conversation and that focuses on the 
ways of dealing with violence. From this third dimension, we can ask what can the methodology used in the groups do in terms of reducing violence?

We understood that participation in a group whose action was to promote the encounter with the possibility of new conversations among the participants favored, for example, that Juliana considered the possibility of replicating the experience in her own collective. In this sense, the methodological proposal of the PCP allows us to retake the idea of language as action (deployed here in speaking and listening, for example) and leads us to affirm that creating a different way of talking - a way in which participants can speak and listen in a new way - coincides with the creation of new ways of acting.

Understanding the dialogue as action (McNamee, 2008) leads us to consider that the possibilities for building partnerships are dependent on modes of conversation in which common interests can be stressed without the risk of erasing differences. Therefore, the technical question that is imposed, and which the structure of conversation implemented in this research sought to respond, is how to create a conversational context that allows participants to feel safe to speak and listen from the place of their differences. Certainly, it was not every difference that the structure implemented was able to receive, as we discussed on axis one. It is also necessary to reflect on what difference we are interested in receiving, and for what, what always refers us to the ethical tension that crosses this type of proposal (Souza \& Moscheta, 2016).

Among the results, we can highlight the conversations about: (1) the initial deception of not having "the enemy" present in the conversation; (2) the difficulty of people with trajectories in militancy to legitimize forms of conversation other than the debate and strangeness of the dialogical format; (3) participation in the PCP as a way of thinking about how one is talking to someone who thinks differently; (4) doubt whether such a conversation format leads to concrete actions to deal with the topic.

In terms of adapting the PCP model to the Brazilian context, we consider that the changes made in the present intervention were important to provide a safe space for the group to be linked to the proposal, with three sequential meetings. The existence of a sequence in the conversations also had a positive effect on most of the participants, making possible that agreements and future proposals would be delineated as indications for taking positions against violence against LGBT people. Such talks could be expanded with a view to adopting more specific strategies to combat violence and to build projects, interventions and meetings that would trigger beyond the groups what was produced in this potential space.

In terms of the limitations of the study, given the space and the cutting chosen, we did not explore the difficulty of talking between LGBT militants and non-LGBT militants or between the various groups of militants, which could inspire further investigations. Another limitation is the need to deepen the "pre-encounter" conversations, to bring more detailed explanations about the methodology, so that the volunteers align more to the proposal even before the groups start, favoring a lesser estrangement in terms of the structure of conversation. The possibility of follow-up of these groups, with follow-up meetings, may be an alternative to keeping alive the invitations and tasks presented in the group in support of the common objective of reducing violence against LGBT people. Investigating the long-term effects of these groups, as suggested in the literature (Dessel \& Rogge, 2008; Wayne, 2008), presents as a future investigative possibility.

\section{References}

Apóstolo, M. V. A., Moscheta, M. S., \& Souza, L. V. (2017). Discursos e posicionamentos em um encontro de diálogo sobre violência a LGBTs. Psicologia USP, 28(2), 266275. doi:10.1590/0103-656420150064

Carrara, S. (2012). Discrimination, policies, and sexual rights in Brazil. Cadernos de Saúde Pública, 28(1), 184189. doi:10.1590/S0102-311X2012000100020

Chasin, R., Herzig, M., Roth, S., Chasin, L., Becker, C., \& Stains, R. R. (1996). From diatribe to dialogue on divisive public issues: Approaches drawn from family therapy. Mediation Quarterly, 13(4), 323-344. doi:10.1002/ crq.3900130408

Dessel, A., \& Rogge, M. E. (2008). Evaluation of intergroup dialogue: A review of the empirical literature. Conflict Resolution Quarterly, 26(2), 199-238. doi:10.1002/crq.230

Efrem Filho, R. (2016). Corpos brutalizados: Conflitos e materializações nas mortes de LGBT [Brutalized bodies: Conflicts and materializations in LGBT deaths]. Cadernos Pagu, (46), 311-340. doi:10.1590/180944492 01600460311

Fernandes, F. B. M. (2013). Assassinatos de travestis e "pais de santo" no Brasil: Homofobia, transfobia e intolerância religiosa [Murder of transvestites and "pais de santo" in Brazil: Homophobia, transphobia and religious intolerance]. Saúde em Debate, 37(98), 485-492. doi:10.1590/S0103-11042013000300012

Forester, J. (2012). On the theory and practice of critical pragmatism: Deliberative practice and creative negotiations. Planning Theory, 12(1), 5-22. doi: $10.1177 / 1473095212448750$

Gergen, K. J.(1999). Social construction and the transformation of identity politics. In F. Newman \& L. Holzman (Eds.), End of knowing: A new developmental way of learning (pp. 102-142). New York, NY: Routledge.

Grupo Gay da Bahia. (2017). Relatório 2016: Assassinatos de LGBT no Brasil 2016 Report: LGBT Assassinations in Brazil]. Retrieved from https://homofobiamata.files. wordpress.com/2017/01/relatc3b3rio-20162.pdf 
Herzig, M. (2011). Fostering welcoming communities through dialogue. Retrieved from http://www. welcomingamerica.org/wp-content/uploads/2011/10/ wac.dialogue.w01.pdf

Herzig, M., \& Chasin, L. (2006). Fostering dialogue across divides: A nuts and bolts guide from the Public Conversations Project. Watertown, MA: Public Conversations Project. Retrieved from http://www. intergroupresources.com/rc/Fostering\%20Dialogue $\% 20$ Across\%20Divides.pdf

Ibáñez Gracia, T. (2001). Municiones para disidentes: Realidad, verdad, política. Barcelona, España: Gedisa.

LaGata, C., Balzer, C., \& Berredo, L. (2016). Informe anual del TMM 2016. Berlin, Germany: Transgender Europe (TGEU). Retrieved from https://transrespect.org/wpcontent/uploads/2016/11/TvT-PS-Vol15-2016.pdf

McNamee, S. (2008). The Lindberg Lecture: 2007 transformative dialogue: Coordinating conflicting moralities. Retrieved from http://citeseerx.ist.psu.edu/viewdoc/ download?doi=10.1.1.527.3088\&rep=rep1\&type $=$ pdf

Mello, L., Avelar, R. B., \& Brito, W. (2014). Políticas públicas de segurança para a população LGBT no Brasil [Public security policies for the LGBT population in Brazil]. Estudos Feministas, 22(1), 297-320. Retrieved from https://periodicos.ufsc.br/index.php/ref/article/ view/S0104-026X2014000100016/26814

Mello, L., Avelar, R. B., \& Maroja, D. (2012). Por onde andam as políticas públicas para a população LGBT no Brasil [Where are the public policies for LGBT population in Brazil]. Sociedade e Estado, 27(2), 289312. doi:10.1590/S0102-69922012000200005

Moscheta, M. S., Souza, L. V., Casarini, K. A., \& ScorsoliniComin, F. (2016). Da (im)possibilidade do diálogo: Conversações públicas e os direitos LGBTs [The (im)possibility of dialogue: Public conversations and LGBT rights]. Psicologia \& Sociedade, 28(3), 516-525. doi:10.1590/1807-03102016v28n3p516

Perucchi, J., Brandão, B. C., \& Vieira, H. I. S. (2014). Aspectos psicossociais da homofobia intrafamiliar e saúde de jovens lésbicas e gays [Psychosocial aspects of homophobia in families and health of young lesbian and gay]. Estudos de Psicologia (Natal), 19(1), 67-76. doi:10.1590/S1413-294X2014000100009

Ramos, S., \& Carrara, S. (2006). A constituição da problemática da violência contra homossexuais: A articulação entre o ativismo e a academia na elaboração de políticas públicas [The problem of violence against homosexuals: The articulation between activism and academy in public policy making]. Physis, 16(2), 185205. doi:10.1590/S0103-73312006000200004
Rasera, E. F. (2017). Diálogo público e trabalho comunitário: $\mathrm{O}$ caso do Projeto Conversações Públicas. In M. A. Grandesso (Org.), Práticas colaborativas e dialógicas em distintos contextos e populações: Um diálogo entre teoria e práticas (pp. 417-432). Curitiba, PR: CRV.

Rasera, E. F., \& Japur, M. (2001). Contribuições do pensamento construcionista para o estudo da prática grupal [Constructionist's contributions for the study of group work]. Psicologia: Reflexão e Crítica, 14(1), 201-209. doi:10.1590/S0102-79722001000100017

Serra, J. P. (2007). Manual de teoria da comunicação. Covilhã, Portugal: Labcom.

Silva, C. N. (Org.). (2007). Diretrizes para o Plano Nacional de Segurança Pública para o enfrentamento da homofobia: Relatório resumido de propostas do I Seminário Nacional de Segurança Pública e Combate à Homofobia [Guidelines for the National Plan of Public Security for Confronting Homophobia: Summary report of proposals of the First National Seminar on Public Security and Combating Homophobia]. Rio de Janeiro, RJ: Grupo Arco-Íris de Conscientização Homossexual e Movimento D'ELLAS.

Souza, L. V., \& Moscheta, M. S. (2016). Ética e diferença no processo de pesquisa com grupos de conversações públicas [Difference and ethics on the research process with public conversations groups]. Athenea Digital, 16(3), 327-346. doi:10.5565/rev/athenea.1829

Trindade, F. M. O., \& Rasera, E. F. (2013). Considerações sobre uma ética relacional. Psico, 44(1), 130-138. Retrieved from http://revistaseletronicas.pucrs.br/ojs/ index.php/revistapsico/article/view/10863/8856

Vianna, C. P. (2015). O movimento LGBT e as políticas de educação de gênero e diversidade sexual: Perdas, ganhos e desafios [The LGBT movement and the gender and sexual diversity education policies: Losses, gains and challenges]. Educação e Pesquisa, 41(3), 791-806. doi:10.1590/s1517-97022015031914

Wayne, E. K. (2008). Is it just talk? Understanding and evaluating intergroup dialogue. Conflict Resolution Quarterly, 25(4), 451-478. doi:10.1002/crq.217

Laura Vilela e Souza is a Professor of the Faculdade de Filosofia, Ciências e Letras de Ribeirão Preto of the Universidade de São Paulo, São Paulo-SP, Brazil.

Murilo dos Santos Moscheta is a Professor of the Departamento de Psicologia of the Universidade Estadual de Maringá, Maringá-PR, Brazil.

Fabio Scorsolini-Comin is a Professor of the Escola de Enfermagem de Ribeirão Preto of the Universidade de São Paulo, São Paulo-SP, Brazil. 
Authors' Contribution:

All authors made substantial contributions to the conception and design of this study, to data analysis and interpretation, and to the manuscript revision and approval of the final version. All the authors assume public responsability for content of the manuscript.

Received: Mar. 22, 2017

1st Revision: Oct. 03, 2017

Approved: Oct. 17, 2017

How to cite this article:

Souza, L. V., Moscheta, M. S., \& Scorsolini-Comin, F. (2019). Public conversations group as resource against LGBT violence. Paidéia (Ribeirão Preto), 29, e2905. doi: http://dx.doi.org/10.1590/1982-4327e2905 